\title{
Assessment of the Demographic Policy Effectiveness in the Republic of Dagestan
}

\author{
Pirmagomed Abdulmanapov ${ }^{1,2^{*}}$
}

\author{
${ }^{1}$ Socio-Economic Research Institute Dagestan Federal Research Centre of the Russian Academy of Sciences, Russia \\ ${ }^{2}$ Dagestan State University of National Economy, Russia \\ *Email: raha77@mail.ru
}

\begin{abstract}
The components of the decline in the Republic of Dagestan's birth rate over the last five-year period are determined, and their contributions to the formation of negative trends are determined. In the Republic of Dagestan conditions, since 2014, a birth rate decreased in all age groups of women, due to which a $75 \%$ negative increase in the number of births compared to 2014. In the region, by 2019, compared to 2014, the number of women of reproductive age decreased by 8.4 thousand people, which ensured a decrease in the birth rate by $4.5 \%$. Moreover, the number of the most active reproductive ages - 20-29 years - decreases, thereby causing negative transformations in the reproductive categories population's age structure. The latter factor added another $20 \%$ negative increase in the dynamics of the birth rate. In the North Caucasus regions, the most significant negative impact on the birth rate over the past five years was exerted by reducing the age-related birth rates. This indicates a decline in the country's effectiveness of demographic policy measures and indicates the need to bring the implemented measures in line with the demographic and socio-economic situation.
\end{abstract}

Keywords: Demographic situation, Demographic development, Demographic policy, The effectiveness of the demographic policy.

\section{INTRODUCTION}

Nowadays, Russia's demographic situation is characterised by a decrease in the population during crisis phenomena in the socio-economic sphere. The state's ability to implement socio-demographic policy has significantly narrowed. Real incomes of the population have decreased, which can directly affect demographic processes. Falling incomes and socio-economic instability undermine the stability of the processes of birth, mortality, migration of the population, as well as cause negative changes in demographic behaviour in the form of a decrease in the need for children, postponement or rejection of the birth of planned children, violation of the correct lifestyle and transformation of migration attitudes.

Simultaneously, the country is implementing a demographic policy to stimulate the birth rate, reduce mortality, and regulate population migration.
Nevertheless, the birth rate in the country and the regions is declining. To improve the implemented population policy considering the socio-economic situation and threats to demographic security, it is necessary to trace the relationship and proportionality of the demographic changes with the implemented demographic development measures. To this end, it is essential to establish common indicative values of indicators of the demographic policy's effectiveness, to separate the impact on the demographic situation of the age structure from the effects of demographic policy measures.

\section{RESEARCH METHODOLOGY}

The study aims to identify the components of the decline in the birth rate in the regions of the North Caucasus Federal District of Russia on the Republic of Dagestan example over the past five years and determine their contributions to the formation of negative trends. 
The scientific problem's selected aspect suggests the need to rely on a wide range of sources, among which an important place is occupied by publications devoted to the issues of demographic reproduction of the population and the influence of state policy on demographic processes. These and other essential aspects of the problem are given considerable attention in Russian and world science.

A significant contribution to developing the theory and methodology of studies of demographic processes was made by foreign researchers (G. Becker, G. Borstrom, R. Easterlin, J. Keynes, F. Osborne, J. Robbins, G. Taylor, J. Huxley, P. Ehrlich), and Russian scientists - E.M. Andreev, V.A. Borisov, D.I. Valentey, A.G. Vishnevsky, V.V. Yelizarov, B.M. Medkov, A.B. Sinelnikov, Kostina S.N., B.S. Khorev, A.E. Ivanova. A significant contribution to the development of concepts of demographic policy in Russia is made by A.I. Antonov, V.N. Arkhangelsky, L.L. Rybakovsky, S.V. Ryazantsev.
D.I. Valentey, in his brief definition, considered demographic policy as the management of population reproduction [1]. V. G. Glushkova's interpretation has a high theoretical value, in which demographic policy is viewed as a system of measures taken by the state to influence the population's natural movement and achieve specific demographic results [2].

The reasoned justification of the demographic policy independence is the A.I. Antonov and V.A. Borisova's position: "The system demographic policy, solving the strategic tasks of preserving the integrity of the state, covers all spheres of the national economy but does not entrust the implementation of several tasks to individual ministries and departments" [3].

In the research, scientific cognition methods were used: system, historical, logical, statistical, methods of synthesis and analysis, including comparative ones. The type of research is observational, analytical, and retrospective. The initial data for the analysis were the birth rate indicators provided by Russia's Federal State

Table 1. Dynamics of birth rate in the regions of the North Caucasus Federal District of Russia for 2014-2019 [4]

\begin{tabular}{|c|c|c|c|c|c|c|c|}
\hline Years & 2014 & 2015 & 2016 & 2017 & 2018 & 2019 & $\begin{array}{c}\text { Growth in 2014- } \\
\text { 2019, thousand } \\
\text { people. }\end{array}$ \\
\hline $\begin{array}{l}\text { Russian } \\
\text { Federation }\end{array}$ & 1942683 & 1940579 & 1888728,99 & 1690307 & 1604344 & 1481074 & -461609 \\
\hline $\begin{array}{l}\text { North Caucasus } \\
\text { Federal District }\end{array}$ & 166577 & 160400 & 154533 & 146894 & 141841 & 135576 & -31001 \\
\hline $\begin{array}{l}\text { The Republic of } \\
\text { Dagestan }\end{array}$ & 56888 & 54867 & 52867 & 50174 & 48120 & 45977 & -10911 \\
\hline $\begin{array}{l}\text { The Republic of } \\
\text { Ingushetia }\end{array}$ & 9858 & 8647 & 7749,99 & 7890 & 8048 & 8252 & -1606 \\
\hline $\begin{array}{l}\text { Kabardino- } \\
\text { Balkar Republic }\end{array}$ & 13396,99 & 12596 & 12128,99 & 11116,99 & 10879 & 9935 & $-3461,99$ \\
\hline $\begin{array}{l}\text { Karachay- } \\
\text { Cherkess } \\
\text { Republic }\end{array}$ & 6318 & 5776 & 5570 & 5120 & 4998 & 5050 & -1268 \\
\hline $\begin{array}{l}\text { The Republic of } \\
\text { North Ossetia- } \\
\text { Alania }\end{array}$ & 10797,99 & 10260,99 & 9901 & 8985 & 9180 & 8575 & $-2222,99$ \\
\hline $\begin{array}{l}\text { The Chechen } \\
\text { Republic }\end{array}$ & 32948,99 & 31867,99 & 29979,99 & 31354,99 & 29946 & 29812,99 & -3136 \\
\hline $\begin{array}{l}\text { Stavropol } \\
\text { Region }\end{array}$ & 36369 & 36385 & 36336 & 32252,99 & 30669,99 & 27974 & -8395 \\
\hline
\end{tabular}


Statistics Service. The necessary indicators for calculating the birth rate are taken from online databases.

\section{RESULTS}

Since 2014, the birth rate in the country and most regions began to decline steadily. In Russia over the past five years, the number of births decreased by more than 461 thousand, and in 2019 this figure reached only $76 \%$ of the 2014 level. In the North Caucasus Federal District, the reduction was 31 thousand births, reaching only $81 \%$ of the indicator's value five years ago. Also, negative growth was observed in all North Caucasus Federal District regions during the analysed period. In the Republic of Dagestan, the birth rate decreased by almost $20 \%$, in the Stavropol Region - by $25 \%$, in the Chechen Republic - by 10\% (table 1).

In the Republic of Dagestan, the number of women of reproductive age has decreased by 2019 compared to 2014. In 2019, the share of the most productive age groups in the female population's age structure decreased. There was also a decrease in the birth rate in all age groups (table 2). The amount and dynamics of age-related indicators depend on many components, including demographic policy measures implementation. After "clearing" the increase of the birth rate in 2019 compared to 2014 from the influence of factors of changes in the number of the reproductive population and shifts in its structure, an assessment of the contribution of measures to stimulate the birth rate on the results of its increase can be made.

Apparently, the drop in the birth rate in the region was the result of all three factors. Let's try to determine the contributions of all the factors that influenced the birth rate decreasing from 2014 to 2019 and identify the demographic policy's role and significance. To do this, we form a set in the form of a table with initial data, which consists of the number of women of reproductive age for 2014 and 2019 by main age groups, the share of age groups in the total number of women of reproductive age and age-specific birth rates.

In 2014-2019, the number of births per year decreased by 10 thousand. To differentiate this decrease in the number of births by three components, a set of mathematical actions is necessary to bring the number of women in age groups and their shares in the total number to a single standard [5]. For example, to calculate the number of births in combination the number of women of reproductive age of 2019 when the age structure of 2014 and age-specific birth rates of 2019, the total number of women of reproductive age of 2019 (836,8 thousand), denoting 1 or $100 \%$, divide the shares of each age group in proportion to the structure for 2014 , received the number in each age group after age multiplied by the corresponding birth rate. Summing up the number of births of all age groups, we deduce the total number of births for 2019 in this variant of combinations.

As noted above, approximately 46 thousand children were born in the Republic of Dagestan in 2019, which is more than 10 thousand less than in 2014. If by 2019 the number of women of the reproductive age groups of 2014 had remained, the number of births would have been 46.7 thousand, which is 0.5 thousand more than the real figure for 2019 (option 7). The resulting difference is $4.5 \%$ of the total negative growth in 2014-2019, which indicates a minor contribution of this factor to the decline in the birth rate (table 3 ).

If in 2019 , there would be the same age structure as 5 years ago (option 6), the total number of births would exceed the real figure by 2 thousand. Transformations in the age structure added about $20 \%$ of the negative increase in birth rate dynamics.

The most significant impact on the region's birth processes over the last five years was reducing the agerelated birth rates. It accounts for about $75 \%$ of the decline in the birth rate since if in 2019 in all age groups the birth rate levels observed in 2014 were maintained,

Table 2. Age structures and age-related birth rates in 2014 and 2019, The Republic of Dagestan [4]

\begin{tabular}{|c|c|c|c|c|c|c|}
\hline Age & \multicolumn{2}{|c|}{$\begin{array}{c}\text { Number of women aged 15-49 } \\
\text { years, thousand people }\end{array}$} & \multicolumn{2}{c|}{ Percentage of age groups } & \multicolumn{2}{c|}{ Age-related birth rates } \\
\hline & 2014 & 2019 & 2014 & 2019 & 2014 & 2019 \\
\hline $15-19$ & 119,0 & 110,6 & 0,141 & 0,132 & 37,50 & 30,90 \\
\hline $20-24$ & 143,8 & 116,2 & 0,170 & 0,139 & 136,50 & 123,70 \\
\hline $25-29$ & 155,2 & 147,5 & 0,184 & 0,176 & 115 & 92,80 \\
\hline $30-34$ & 123,2 & 145,9 & 0,146 & 0,174 & 76,90 & 65,90 \\
\hline $35-39$ & 104,6 & 116,2 & 0,124 & 0,139 & 41,60 & 36,40 \\
\hline $40-44$ & 100,9 & 101,7 & 0,119 & 0,122 & 9 & 8,60 \\
\hline $45-49$ & 98,6 & 98,7 & 0,117 & 0,118 & 0,50 & 0,50 \\
\hline Total & 845,2 & 836,8 & 1 & 1 & 19,1 & 14,8 \\
\hline
\end{tabular}


Table 3. The number of births under various combinations of factors affecting the birth rate, 2019, The Republic of Dagestan

\begin{tabular}{|c|c|c|c|c|}
\hline Options & $\begin{array}{c}\text { Number of women } \\
\text { aged 15-49 }\end{array}$ & Age structure & Age indicators & Number of births \\
\hline 1 & 2014 & 2014 & 2014 & 56,7 \\
\hline 2 & 2014 & 2014 & 2019 & 48,7 \\
\hline 3 & 2014 & 2019 & 2014 & 54,53 \\
\hline 4 & 2019 & 2014 & 2014 & 56,15 \\
\hline 5 & 2019 & 2019 & 2014 & 53,99 \\
\hline 6 & 2019 & 2014 & 2019 & 48,22 \\
\hline 7 & 2014 & 2019 & 2019 & 46,71 \\
\hline 8 & 2019 & 2019 & 2019 & 46,25 \\
\hline
\end{tabular}

the total number of births would correspond to the value of 54 thousand (option 5).

A large share in the decrease in the number of births due to decrease in the birth rate in groups indicates the weak effectiveness of the demographic policy implemented in the country and low efficiency in the regions of the North Caucasus. The size and dynamics of age-related indicators, as noted above, depends on many components, including the implementation of demographic policy measures [6]. The demographic policy in Russia, supplemented in 2007 by new measures, continues to be implemented. During all this time, it was only improved and supplemented [7]. Nevertheless, the country's birth rate dynamics and in most regions since 2014 continues to decline [8]. It is caused by economic factors that have opposite vectors of influence on the birth processes relative to demographic policy measures; the main one is the decrease in the population's real monetary incomes due to the currency crisis of 20142015 Russia [9]. As the study results by James Defronzo confirm, it is the actual income that has always had a significant impact on the birth rate in marriage [10]. The decrease in family income and the associated decline in people's quality of life most often affects the birth rate, mortality rate, and migration activity [11]. Currently, in Russia, families have been forced to postpone the birth of another child until better times or completely abandon it.

The process of urbanisation could also influence the birth rate processes in the North Caucasus regions. However, urbanisation in reducing the birth rate remains long-term trends characterise a subject of debate in scientific circles since the decline in the birth rate under the influence of changes in the place of residence. Also, a researcher from the Max Planck Institute for Demographic Research (Germany), Mathias Lerch, believes that in developing countries, the differences in fertility between rural and urban areas remain more limited due to the parallel decreasing of the birth rate by residence type [12]. Consequently, urbanisation has played a minor role in reducing the Republic of Dagestan's birth rate since 2014.

Thus, the decline in the birth rate in the Republic of Dagestan since 2014 is due to the simultaneous effect of all three components of demographic growth: the number of women of reproductive age, structural shifts towards a decrease in the number of women of the most active reproductive ages (20-29 years) and changes in agerelated birth rates. The decline in birth rates in all age groups was the primary determinant of decreasing the region's birth rate, which accounts for three-quarters of the number of births' negative increase.

\section{CONCLUSIONS}

In the Republic of Dagestan's conditions, since 2014, there has been a decrease in the birth rate in all age groups of women, which provided a $75 \%$ negative increase in the number of births compared to 2019. This circumstance coincides with a decrease in the number of women of reproductive age. In the region, by 2019 , compared to 2014 , the number of reproductive-age women decreased by 8.4 thousand, which led to a decrease in the birth rate by $4.5 \%$. Moreover, the number of the most active reproductive ages - 20-24 and 25-29 years-is decreasing, thereby causing negative transformations in the reproductive categories population's age structure. This factor also significantly impacted demographic dynamics, adding about $20 \%$ of the negative increase in birth rate dynamics.

The decline in age coefficients is evidence of the decrease in the effectiveness of demographic policy measures. Obviously, without significant financial injections and the introduction of new strong demographic policy measures as a matter of urgency, its efficacy will significantly decrease. 


\section{REFERENCES}

[1] Fundamentals of population theory: A textbook for econ. special universities, Ed. D.I. Valentey. 3rd ed., reprint. and add. Moscow: "Higher School", 1986, 374 p.

[2] Demographics: Workbook, Ed. by V.G. Glushkova, Yu.A. Simagina, 4th ed., reprint. and add. M., KNORUS, 2010, 288 p.

[3] A.I. Antonov, V.A. Borisov, Dynamics of the Russian population in the 21 st century and priorities of demographic policy, Moscow: Klyuch-S, 2006, $192 \mathrm{p}$.

[4] Rosstat, Data showcase. Retrieved from: https://www.gks.ru/

[5] V.N. Arkhangelsky, A.E. Ivanova, L.L. Rybakovsky, The effectiveness of the demographic policy of Russia, [V.N. Arkhangelsky, A.E. Ivanova, L.L. Rybakovsky; ed. L.L. Rybakovsky], M.: Publishing House "Econ-Inform", 2016, 307 p.

[6] E.V. Smirennikov, A.V. Ukhanov, L.V. Voronina, Review of modern methodological approaches to assessing demographic potential, Fundamental Research 11-2 (2018) 307-313.

[7] N.V. Zykova, T.N. Ushakova, O.V. Ikonnikova, Study of the relationship between the quality of life and socio-economic indicators of the region, Economics and Entrepreneurship 12 (2018) 342344.

[8] S. Kostina, E. Zaitseva, Reproduction of human resources in urban and rural areas of Russia: what the number of children depends on, Proceedings of the 2nd International Conference on Education Reform, Management and Applied Social Science (ERMASS 2019) - Xiamen, 2019 [Electronic resource]. Retrieved from: http://dpiproceedings.com/index.php/ dtssehs/issue/view/386 (accessed 12.02.2020)

[9] P.G. Abdulmanap, The impact of socio-economic changes on demographic processes in the North Caucasus Federal District regions, Regional problems of economic transformation 4(114) (2020) 52-62.

[10] J. Defronzo, Cross-Sectional Areal Analyses of Factors Affecting Marital Fertility: Actual versus Relative Income, Journal of Marriage and Family Vol. 38(4) (1976) 669-676. Demographics: Workbook, Ed. by V.G. Glushkova, Yu.A. Simagina. 4th ed., reprint. and add. M., KNORUS, 2010, 288 p.
[11] S.V. Ryazantsev, L.L. Rybakovsky, V.A. Bezverbny, Issues of demographic development of Russia in Presidential addresses impact the demographic policy's effectiveness. Retrieved from: http://isprras.ru/pics/File/dem-q.pdf (date accessed: 07.05.2017).

[12] M. Lerch, Urban and rural fertility transitions in the developing world: a cohort perspective, Population and Development Review Vol. 45(2) (2018) 301320. DOI. https://doi.org/10.1111/padr.12220 